\section{Factors associated with the prevalence of hypertension and control practices among elderly residents of São Paulo city, Brazil}

\author{
Fatores associados à prevalência de hipertensão \\ e medidas de controle entre idosos residentes \\ no Município de São Paulo, Brasil
}

\section{Factores asociados con la prevalencia de hipertensión y medidas de control entre ancianos residentes en el Municipio de São Paulo, Brasil}

Telma de Almeida Busch Mendes 1 Moisés Goldbaum 1 Neuber José Segri 2 Marilisa Berti de Azevedo Barros 3 Chester Luiz Galvão César 2 Luana Carandina 4

\footnotetext{
${ }^{1}$ Faculdade de Medicina, Universidade de São Paulo, São Paulo, Brasil. 2 Faculdade de Saúde Pública, Universidade de São Paulo, São Paulo, Brasil. 3 Faculdade de Ciências Médicas, Universidade Estadual de Campinas, Campinas, Brasil.

4 Faculdade de Medicina de Botucatu, Universidade Estadual Paulista, Botucatu, Brasil.

Correspondence T. A. B. Mendes Departamento de Medicina Preventiva, Faculdade de Medicina, Universidade de São Paulo.

Av. Dr. Arnaldo 455, 20 andar, São Paulo, SP 01246-903, Brasil. telma.busch@yahoo.com.br
}

\begin{abstract}
The aim of this study was to analyze the prevalence of hypertension and control practices among the elderly. The survey analyzed data from 872 elderly people in São Paulo, Brazil, through a cluster sampling, stratified according to education and income. A Poisson multiple regression model checked for the existence of factors associated with hypertension. The prevalence of self-reported hypertension among the elderly was $46.9 \%$. Variables associated with hypertension were self-rated health, alcohol consumption, gender, and hospitalization in the last year, regardless of age. The three most common measures taken to control hypertension, but only rarely, are oral medication, routine salt-free diet and physical activity. Lifestyle and socioeconomic status did not affect the practice of control, but knowledge about the importance of physical activity was higher among those older people with higher education and greater income. The research suggests that health policies that focus on primary care to encourage lifestyle changes among the elderly are necessary.
\end{abstract}

Hypertension; Health Surveys; Health Services; Aged

\section{Resumo}

O objetivo deste estudo foi analisar a prevalência de hipertensão e práticas de controle em idosos. Inquérito transversal analisou dados de 872 idosos de São Paulo, Brasil, por meio de uma amostra por conglomerados, estratificada segundo escolaridade e renda. O modelo de regressão múltiplo de Poisson verificou a existência de fatores associados à hipertensão. A prevalência de hipertensão referida entre os idosos foi de 46,9\%. As variáveis associadas à hipertensão foram autopercepção de saúde, consumo de álcool, sexo e hospitalização no último ano, independentemente da idade. As três medidas mais adotadas para o controle da hipertensão, embora pouco praticadas, são tomar medicação oral de rotina, dieta sem sal e atividade física. O estilo de vida e a condição socioeconômica não influenciaram a prática de controle, mas o conhecimento sobre a importância da atividade física foi maior entre os idosos com mais escolaridade e renda. Fazemse necessárias políticas de saúde com foco na atenção primária que incentivem mudanças no estilo de vida dos idosos.

Hipertensão; Inquéritos Epidemiológicos; Serviços de Saúde; Idoso 


\section{Introduction}

Chronic diseases resultant from the ageing process and unhealthy lifestyles are the greatest factors responsible for the high morbiditymortality rates, particularly among the elderly, and for placing immense pressure on the health system ${ }^{1}$. Chronic diseases, especially cardiovascular ones, are the main cause of death among the elderly population throughout the world 2 . Among the main risk factors for cardiovascular disease are diabetes mellitus and hypertension, which are independent factors that together may be even more aggravating 3 .

In the United States about 77.9 million adults ( 1 in every 3 ) have high blood pressure. Men and women are equally likely to develop high blood pressure during their lifetimes. However, after the age of 65, the condition is more likely to affect women than men ${ }^{4}$. The estimated prevalence of hypertension found among the elderly (65 years old and above) in Brazil in the year 2008, was $60.6 \%$, with a significant difference between genders 5 .

Even though the Brazilian Society for Hypertension has well defined criteria for the treatment of hypertension using medicines, and despite the existence of control strategies, in some cases, without pharmacological measures, the control indexes are still low. Such control is complex for several reasons including the cost of medication, the need to combine more than one medicine, collateral effects, low adhesion to the treatment, and difficulties related to access and use of health services 6 .

This lack of control of hypertension can also be found in developed countries, where less than $25 \%$ of patients with this disease have their blood pressure levels controlled, while in developing countries this number does not reach $10 \% 7$. For this reason, actions involving dietary and lifestyle changes have been more recommended 8 .

Knowledge about the demographic and socioeconomic profiles of the elderly with hypertension and the information they have about the disease and its control strategies, allows for the development of epidemiological care and a better approach, thereby empowering the elderly. Furthermore, it supports the planning and development of public policies for a better placement of the available resources aiming at obtaining more effective results in the access and use of health services by the elderly.

The aims of this study were to identify related factors to the prevalence of hypertension in the elderly according to demographic and socioeconomic conditions, and to analyze health conditions and the lifestyle of the elderly, in addition to investigating their knowledge about measures and practices used to control hypertension.

\section{Methods}

The study involved a population-based cross sectional study that included 872 non-institutionalized elderly people (60 years old and over), residing in São Paulo city in 2003. This research is part of the Health Survey in São Paulo City project (ISA-Capital).

In the ISA-Capital survey, a total of 3,357 individuals were randomly selected by two-stage (census-tract and household) cluster sampling. The sample was also stratified according to the education of the head of the family, dividing the percentage of heads with academic degrees into three categories: less than $5 \%$, between $5 \%$ and $25 \%$, and more than $25 \%$.

A minimum sample size of 420 people was estimated for each domain of age and gender, taking into account possible losses, and based on a prevalence estimate of $50 \%(\mathrm{p}=0.50)$, with a confidence level of $95 \%(\mathrm{z}=1.96)$, sample error of 0.06 , and design effect of 1.5.

The information was obtained using questionnaires applied by interviewers and answered by the persons selected. In addition, all interviews were carried out by qualified interviewers with at least complete secondary school.

The questionnaire was organized in blocks and most of the questions were closed, with predetermined alternatives. Not all blocks were applied to all interviewees, since some themes were specific for certain individual conditions.

The variables included in the study were: (a) presence of reported arterial hypertension (having or not having hypertension); (b) demographic - gender, age, ethnic group, religion, marital status, level of education of head of the family, paid work; (c) socioeconomic - education, family income per capita (measured as a multiple of the minimum wage); (d) health conditions - "selfrated health", reported morbidity 15 days prior to the interview, number of chronic diseases, hospitalization in the 12 months prior to the interview; (e) lifestyle - weekly alcohol consumption, abuse/addiction to alcohol assessed by the CAGE questionnaire ${ }^{9}$, and smoking status (the alcohol use frequency was classified in: never drank/ don't drink anymore; up to two times a month; one to three times a week; four to seven times a week).

Only seniors who reported having hypertension answered an extra block of questions. It was asked who had told them that they were hypertensive (doctor or someone else), what did they 
do to control the blood pressure, if they usually go to the health center or doctor periodically to control it, the reason for not seeking out a doctor to control pressure, how long has it been since they sought a doctor or a health service, whether they had participated in discussion groups about the disease, which they had knowledge about it, what should be done to control it and what they actually did.

The survey commands of the statistical software Stata 10 (Stata Corp., College Station, USA) were used to analyze the data considering the complex sample design. Thus, the participants' weight (main weight) was incorporated in the analysis based on the sampling fractions and post-stratification adjustment.

Association tests were performed using Pearson's chi-square tests (Rao-Scott) with a significance level of $5 \%$ in order to verify the existence of a statistical association between demographic and socioeconomic variables, and lifestyle and health status, according to the reported presence of hypertension $(\mathrm{p}<0.05)$. Prevalence estimates were performed and prevalence ratios (PR) were calculated for reported hypertension with confidence intervals of $95 \%$ (95\%CI).

The Poisson regression model with robust variance was used 10 in order to verify the existence of associated factors to hypertension. The majority of the variables were dichotomized and those which presented $\mathrm{p}<0.20$ in the univariate analysis were considered for the introduction in the model, adjusted by age (stepwise forward procedure).

This research project was approved by the Research Ethics Committee of the Medical School of the University of São Paulo, protocol no 0217/09.

\section{Results}

Of the 3,357 individuals interviewed in the ISA-Capital survey, a total of 872 were elderly people aged 60 or above, of which 451 were female; $60.3 \%$ (95\%CI: 56.54-63.98) and 421 male; 39.7\% (95\%CI: 36.02-43.46) and were considered for this study. The mean age of the participants was 70.23 years with no significant difference between men (69.75 years) and women (70.55 years), $(p=0.094)$.

Regarding the 872 subjects interviewed, only 842 completed the questionnaires. This difference can be explained by refusals to participate and other reasons, despite identifying the elderly at home and successive visits. Among the 842 elderly, 395 reported hypertension and in all but one instance [(394 (99.8\%) 95\%CI (98.25-99.97)], the diagnosis had been made by a doctor, on average 12 years before the interview [95\%CI (10.88-13.27)].

The prevalence of reported arterial hypertension was higher among women, non-white individuals, widows and widowers, those who were not the head of the family, those who did not have any paid activity, those with lower educational levels and those with lower income (Table 1).

Considering the lifestyle variables, hypertension was associated with consumption of alcohol, $(p<0,001)$, self-rated health $(p<0.001)$ and hospitalization $(p=0.032)$. Although alcohol consumption has a significant influence upon the prevalence of hypertension, its association is inverse. There was no association between hypertension and smoking (Table 2).

Among the elderly with hypertension, the percentage who never drank was higher compared to the non-hypertensive group, $73.7 \%$ and $55.9 \%$ respectively.

Concerning health status, the prevalence of hypertension was 1.84 times higher among the elderly who self reported as having bad/very bad health when compared to those who self reported having great/excellent health. Accordingly, it was verified that the prevalence of hypertension was $34 \%$ higher among the elderly who were hospitalized at least once compared to those who had been hospitalized in the year prior to the interview (Table 2).

Among the individuals with hypertension, the number of hospitalizations in the last year was also higher (17.4\%) compared to individuals without hypertension $(10.4 \%) \mathrm{p}<0.0032$ (data not shown in table). Regarding the number of chronic diseases, it was noticed that the presence of one or more diseases was higher among hypertensive patients $(71.7 \%)$ compared to non-hypertensive patients (45.5\%) This association does not persist for three or more diseases, $\mathrm{p}<0.001$ (data not shown in table).

The variables associated with hypertension and which presented a $\mathrm{p}$-value $<0.20$ were introduced in the Poisson regression model in the following sequence: self-rated health perception, frequency of alcohol use, gender, marital status, hospitalization, level of education, income, head of family condition, ethnic group, smoking status, and religion. The Poisson multiple regression model showed a higher prevalence ratio of hypertension among the elderly who presented self perception of health as bad/very bad, among those who never drank or do not drink anymore, among women, and among those who were hospitalized at least once in the previous year. The variable marital status appeared to be inversely associated with hypertension, when comparing single people to those who were married (Table 3 ). 
Prevalence of arterial hypertension according to demographic and socioeconomic variables in elderly aged 60 years and over ( $n=842$ ). ISA-Capital, São Paulo State, Brazil, 2003.

\begin{tabular}{|c|c|c|c|c|}
\hline Variables & $\mathbf{n}$ & Prevalence (\%) * & PR $(95 \% \mathrm{Cl})$ crude & $\mathrm{p}$-value ** \\
\hline \multicolumn{5}{|l|}{ Gender } \\
\hline Male & 405 & 37.95 & 1.00 & 0.0003 \\
\hline Female & 437 & 51.56 & $1.36(1.13-1.63)$ & \\
\hline \multicolumn{5}{|l|}{ Age group (years) } \\
\hline $60-69$ & 458 & 43.78 & 1.00 & 0.4305 \\
\hline $70-79$ & 297 & 48.34 & $1.10(0.92-1.32)$ & \\
\hline 80 and more & 87 & 50.02 & $1.14(0.88-1.48)$ & \\
\hline \multicolumn{5}{|l|}{ Race/Color } \\
\hline White & 585 & 43.85 & 1.00 & 0.0429 \\
\hline No white & 256 & 53.64 & $1.22(1.01-1.47)$ & \\
\hline \multicolumn{5}{|l|}{ Religion } \\
\hline Catholic & 601 & 46.01 & 1.00 & 0.1592 \\
\hline No religion & 26 & 28.87 & $0.63(0.26-1.51)$ & \\
\hline Evangelical & 158 & 50.66 & $1.10(0.86-1.40)$ & \\
\hline Spiritualist & 16 & 22.90 & $0.50(0.14-1.71)$ & \\
\hline Others & 41 & 57.06 & $1.24(0.80-1.93)$ & \\
\hline \multicolumn{5}{|l|}{ Marital status } \\
\hline Married & 481 & 44.83 & 1.00 & 0.0023 \\
\hline Single & 32 & 22.16 & $0.49(0.24-1.01)$ & \\
\hline Divorced/Separated & 65 & 36.53 & $0.81(0.58-1.15)$ & \\
\hline Widow(er) & 247 & 53.72 & $1.20(1.01-1.43)$ & \\
\hline \multicolumn{5}{|l|}{ Head of the family } \\
\hline Yes & 575 & 42.58 & 1.00 & 0.0228 \\
\hline No & 264 & 52.22 & $1.23(1.02-1.47)$ & \\
\hline \multicolumn{5}{|l|}{ Education (years) } \\
\hline $0-7$ & 660 & 49.68 & $1.31(1.04-1.66)$ & 0.0124 \\
\hline 8 or more & 168 & 37.79 & 1.00 & \\
\hline \multicolumn{5}{|c|}{ Income per capita (multiple of the } \\
\hline \multicolumn{5}{|c|}{ minimum) } \\
\hline Up to 2.5 & 642 & 48.96 & 1.00 & 0.0200 \\
\hline 2.5 or more & 200 & 40.32 & $0.82(0.69-0.98)$ & \\
\hline
\end{tabular}

95\% Cl: 95\% confidence interval; PR: prevalence rate.

* Sample weights were taken into account;

$\star *$ Values in bold present statistical significance $(p<0.05)$.

Concerning the participation of the elderly in discussion groups about the control of high blood pressure, a total of 392 individuals with hypertension answered this question. Of this total, $88.9 \%$ responded that they did not participate and only $11.1 \%$ did.

The involvement in discussion groups about the disease only influenced the knowledge about the control practice of a low-salt diet $(\mathrm{p}<0.0001)$; there was no significant statistical differences upon the other control measures, such as practicing physical activity or medication (Figure 1).
Concerning knowledge about measures and practices for the control of hypertension, there was no significant difference between genders ( $\mathrm{p}>0.005)$.

It was verified that the great majority of the elderly (98.4\%) reported practicing some kind of control measure; however, when these practices were analyzed individually, it was demonstrated that the control practice is still precarious (data not shown in table).

The three most commonly cited control measures for high blood pressure, although still little 


\begin{tabular}{|c|c|c|c|c|}
\hline \multicolumn{5}{|c|}{$\begin{array}{l}\text { Prevalence of arterial hypertension according to lifestyle and health status of elderly aged } 60 \text { years and over. ISA-Capital, São } \\
\text { Paulo State, Brazil, } 2003 .\end{array}$} \\
\hline Variables & $\mathrm{n}$ & Prevalence $(\%)$ * & PR $(95 \% \mathrm{Cl})$ crude & p-value ** \\
\hline \multicolumn{5}{|l|}{ Smoking habit $(n=836)$} \\
\hline Non-smoker/Ex-smoker & 708 & 47.13 & 1.00 & 0.1542 \\
\hline Smoker & 128 & 39.58 & $0.84(0.65-1.09)$ & \\
\hline \multicolumn{5}{|l|}{ Alcohol use ( $n=832)$} \\
\hline Never/Do not drink & 546 & 52.75 & $1.78(1.31-2.42)$ & $<0.0001$ \\
\hline Up to 2 times per month & 117 & 38.27 & $1.29(0.95-1.74)$ & \\
\hline 1-7 times per week & 169 & 29.63 & 1.00 & \\
\hline \multicolumn{5}{|l|}{ Alcoholism/CAGE (n = 293) } \\
\hline Negative $(<2)$ & 251 & 33.59 & 1.00 & 0.8013 \\
\hline Positive $(\geq 2)$ & 42 & 35.72 & $1.06(0.65-1.75)$ & \\
\hline \multicolumn{5}{|c|}{ Self assessment of health $(n=840)$} \\
\hline Great/Excellent & 162 & 23.72 & 1.00 & $<0.0001$ \\
\hline Good & 543 & 49.56 & $2.09(1.65-2.65)$ & \\
\hline Bad/Very bad & 135 & 67.37 & $2.84(2.17-3.72)$ & \\
\hline \multicolumn{5}{|l|}{ Morbidity 15 days $(n=842)$} \\
\hline No & 616 & 47.12 & 1.00 & 0.3608 \\
\hline Yes & 226 & 43.55 & $0.92(0.77-1.10)$ & \\
\hline \multicolumn{5}{|l|}{ Hospitalization $(n=839)$} \\
\hline None & 735 & 44.05 & 1.00 & 0.0032 \\
\hline One or more & 104 & 59.01 & $1.34(1.14-1.58)$ & \\
\hline
\end{tabular}

95\% Cl: 95\% confidence interval; PR: prevalence rate.

* The sample weights were taken into account;

** Values in bold present statistical significance $(p<0.05)$.

practiced among the elderly with hypertension, were: taking routine oral medication $(87.2 \%$, 95\%CI: 81.7; 91.1), a low-salt diet $(33.4 \%, 95 \% \mathrm{CI}$ : $27.6 ; 39.8)$, and practicing physical activity $(5.4 \%$, 95\%CI: 3.1; 9.3) In particular, taking routine oral medication was the most commonly known and practiced among the three measures mentioned by the elderly, and physical activity the least.

Of a total of 395 individuals with hypertension, $59.8 \%$ (95\%CI: 51.7; 67.3) of the elderly knew of the importance of taking routine oral medicine and, as previously mentioned, $87.2 \%$ practiced this measure. Among men, 62.7\% (95\%CI: 51.6; 72.6) knew that taking routine medication was important for the control and 85.5\% (95\%CI: 76.5; 91.5) of them reported taking it; among women, the percentages were $58.4 \%$ (95\%CI: $49.5 ; 66.7)$ and $88 \%$ (95\%CI: 82.1; 92.1) respectively. Concerning lifestyle, smoking status, the frequency of alcohol use and its abusive as measured by CAGE did not influence the knowledge about what is important to be done in order to control hypertension (data not shown). Those elderly who smoked were the ones who least likely to practice a low-salt diet (11.2\%, 95\%CI: $5.2 ; 22.3)$ compared to ex-smokers, $(42.2 \%, 95 \%$ CI: 32.6 ; 52.6) and non-smokers, (34\%, 95\%CI: 26.0; 43.0) $(\mathrm{p}=0.022)$. In addition, smokers are the ones who take less routine oral medication $(76.9 \%, 95 \% \mathrm{CI}$ : $60.6 ; 87.8)(p=0.0356)$. The elderly who presented abusive levels of alcohol consumption practiced less low-salt diets (4.3\%) and less control (29\%) of hypertension compared to those with negative CAGE ( $\mathrm{p}=0.0131)$.

As regards to the socioeconomic conditions, knowledge of the importance of physical activity as a control measure of hypertension was found to be higher among those with better education levels $(37.4 \%)$ compared to those with low levels $(3.67 \%)$. ( $p=0.0033)$ and greater income $(19.3 \%$ vs. $4.7 \%)(p=0.0025)$ respectively. When investigating the influence of education on the knowledge that the elderly had on measures to control blood pressure, there was no statistical significance for infirm measures, although there was a tendency for some measures like dieting without salt $(\mathrm{p}=0.0058)$, and physical activity $(p=0.0052)$. The highest income significantly 
Poisson multiple regression model. Variables associated to arterial hypertension in elderly aged 60 and over $(n=842)$. ISACapital, São Paulo, Brazil, 2003

\begin{tabular}{|c|c|c|}
\hline Variables & PR $(95 \% \mathrm{Cl})$ * crude & PR $(95 \% \mathrm{Cl})$ * adjusted ** \\
\hline \multicolumn{3}{|l|}{ Self assessment of health } \\
\hline Great/Excellent & 1.00 & 1.00 \\
\hline Good & $2.09(1.65-2.65)$ & $1.91(1.50-2.44)$ \\
\hline Bad/Very bad & $2.84(2.17-3.72)$ & $2.35(1.79-3.08)$ \\
\hline \multicolumn{3}{|l|}{ Alcohol use $(n=832)$} \\
\hline Never/Do not drink & $1.78(1.31-2.42)$ & $1.40(1.05-1.86)$ \\
\hline Up to 2 times per month & $1.29(0.95-1.74)$ & $1.14(0.83-1.57)$ \\
\hline 1-7 times a week & 1.00 & 1.00 \\
\hline \multicolumn{3}{|l|}{ Gender } \\
\hline Male & 1.00 & 1.00 \\
\hline Female & $1.36(1.13-1.63)$ & $1.33(1.06-1.65)$ \\
\hline \multicolumn{3}{|l|}{ Marital status } \\
\hline Married & 1.00 & 1.00 \\
\hline Single & $0.49(0.24-1.01)$ & $0.46(0.23-0.96)$ \\
\hline Divorced/Separated & $0.81(0.58-1.15)$ & $0.66(0.43-1.00)$ \\
\hline Widow(er) & $1.20(1.01-1.43)$ & $0.96(0.78-1.18)$ \\
\hline \multicolumn{3}{|l|}{ Hospitalization $(n=839)$} \\
\hline None & 1.00 & 1.00 \\
\hline One or more & $1.34(1.14-1.58)$ & $1.20(1.01-1.43)$ \\
\hline \multicolumn{3}{|l|}{ Age group (years) } \\
\hline $60-69$ & 1.00 & 1.00 \\
\hline $70-79$ & $1.10(0.92-1.32)$ & $1.02(0.86-1.22)$ \\
\hline 80 and more & $1.14(0.88-1.48)$ & $1.02(0.80-1.30)$ \\
\hline
\end{tabular}

95\% Cl: 95\% confidence interval; PR: prevalence rate.

* Sample weights were taken into account;

** Poisson regression model adjusted by the variables presented in table.

influenced knowledge about only two of these measures ( $\mathrm{p}=0.0242$ and 0.0192 , respectively).

By analyzing the socioeconomic influence on the adoption of control measures, neither income nor education had a significant influence ( $p>0.05$ ) (data not shown in table).

Regarding the periodicity in demand for health services or doctor because of high blood pressure, a total of 395 elderly hypertensive patients, $70.1 \%$ (273) said yes, routinely sought out a doctor, $18.7 \%$ (77) did not and $11.2 \%$ (45) of older adults said they only sought health services when they had problem as can be seen in Figure 2 .

\section{Discussion}

The prevalence of reported hypertension (46.9\%) in the elderly residing in São Paulo city was found to be similar in São Paulo State $-43.9 \% 11$ and $46.8 \% 12$ - and similar to the one found in
Canada in 2005 (45\%) 13 and lower than the one found in cities such as Bambuí, Minas Gerais State (61.5\%) 14 and Campinas, São Paulo State (51.8\%) for the same age group 15 .

Concerning the higher prevalence among non-white individuals, a similar result was found in Campinas 15 and in the United States 16. Economic conditions, lifestyle 1, educational levels 17 , income opportunities that are dependent on these factors, racism 18 and access to health services 19 are all variables that should be considered in order to explain unequal opportunities between white and non-white subjects. Hypertension among black individuals was $41.4 \%$ compared to $28.1 \%$ among white individuals 20 . According to Cacciamali \& Hirata 21 , one of the factors that may explain such racial inequality is the heritage of African slavery in Brazil, as well as the patterns of a patriarchal society. Such conditions led to a social and working discrimination that perpetuated those 
Knowledge of hypertension control practices by the elderly according to participation $(n=336)$ and non-participation in discussion groups about the disease. ISA-Capital, São Paulo State, Brazil, 2003.
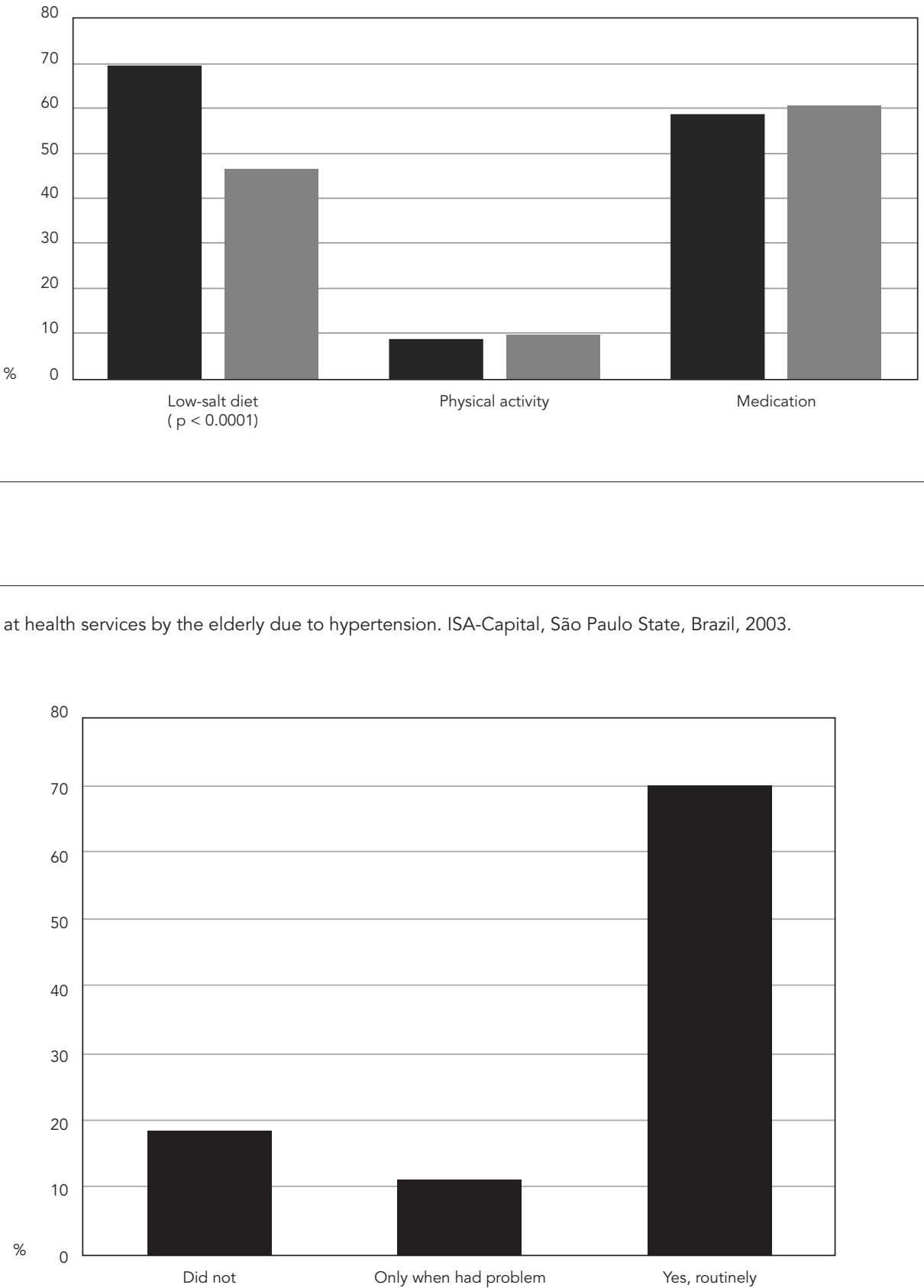

differences, which may justify the worse educational and health conditions.

Taking gender into account, a prevalence of hypertension was found to be $33 \%$ higher in women; with the same finding made in the cities of Campinas 15, Santos 22, São Paulo State, and also in the international literature 23 .

The fact is that disease prevalence may also be influenced by the individual's access to health services, by socioeconomic disadvantages, and 
by the self-perception of health status. Women have better self-perception of health, take more care of themselves, seek out health services with greater frequency, and therefore can better identify diseases $11,24,25$. This may be a reflex of a society where men are considered the stronger gender, which reinforces this behavior among men, and calls for a reassessment of the types of assistance made available for the elderly.

Being a widow(er), not being the head of the family, and not practicing any kind of working activity were considered by the univariate analysis as factors associated to a greater prevalence of hypertension. These factors may be related to the higher percentage of widows who were not the head of the family and were not actively working.

We observed an inverse association between the elderly who were single in relation to the prevalence of hypertension that may be related to a lower demand for health care among singles, who therefore have less of a chance of being diagnosed with hypertension, and thereby reported less hypertension.

The socioeconomic conditions analyzed by educational levels and income per capita revealed a greater prevalence of hypertension among the elderly with lower educational levels and lower income and this association was also found in other studies 15,26. The educational levels may facilitate not only the acquisition of knowledge of better control practices, but also better working opportunities and income 27 which facilitates the access to health services, medical appointments, acquisition of medication, and ongoing treatment 13,26. The racial and gender discrimination, and the heritage of slavery may explain the elevated degree of inequity in the working market and opportunities, especially in terms of access to education.

The elderly who drank less presented a higher prevalence of hypertension. This same inverse effect may be found by another study 15 .

This result may have been influenced by the confounding variable gender, since most women in this age group have hypertension. Furthermore, despite the advantages of speed and lower costs of the cross-sectional study, it has its limitations since it does not identify causality, whether the factors associated with hypertension came before or after it, since expositions and outcomes are collected at the same moment. Another factor to be considered is the average age (70) of the elderly who may justify the survival bias. This may also explain the lack of significance between smoking status and hypertension and the inverse relation with the frequency of alcohol use found in the study. The higher prevalence among in- dividuals who consume more alcohol may be related to the fact that when someone becomes aware of the diagnosis, they may be more ready to change their lifestyle. But when analyzing the prevalence of hypertension among the elderly who had quit smoking $(\mathrm{n}=116,24.6 \%)$ and nonhypertensive patients $(n=114,25.1 \%)$ there was found to be no statistically significant difference and we might infer that seniors have quit smoking when hypertension was discovered.

Smoking is associated with an increased cardiac rate and (minimum) diastolic blood pressure, and the study showed that smokers have a six times reduced elastic capacity in their arterial system when compared to non-smokers, although this fact was not found to be statistically significant in the current study 28 .

The prevalence of hypertension among the elderly who self reported their health as bad/very bad was 2.84 (95\%CI: 2.17 ; 3.72) times the prevalence who had a self-perception of excellent/ great and the prevalence of hypertension among those who were hospitalized at least once in the past 12 months was 1.34 times (95\%CI: 1.14 ; 1.58) the prevalence compared with those who had never been hospitalized. These results reinforce the relationship between self-perceived health and morbidity found in other studies 29,30,31. These findings were different from another study, where the prevalence of hypertension among the elderly who self assessed their health as bad/very bad was $93 \%$ higher 32 although in this last study, the odds ratio (OR) had been used to interpret the results.

The morbidity reported 15 days prior to the interview was not statistically significant in the univariate analysis. This data is compatible with a study that revealed that hypertension influences quality of life and health less than other chronic diseases 11. This fact was explained by the existence of more structured programs that facilitate the early diagnosis and prevent greater consequences, as well as by the fact that some studies showed higher use of medication by those patients indicating greater access to services in comparison to other patients 33 . However, the findings of this study indicate the need for certain urgent changes. Nevertheless, an important parcel of the adult population with hypertension does not know they have it; and many of those who do know are not being treated adequately.

In the present study, the prevalence of chronic diseases drew attention since, although statistically significant, the number of chronic diseases reported was only higher among patients with hypertension when compared to those without hypertension who reported one or two diseases. 
Analyzing the final Poisson regression model (adjusted PR), a higher prevalence of hypertension was found among the elderly who self-assessed their health as bad/very bad and good, the elderly who never drank or do not drink anymore (inverse relation), among women, and among those who had been hospitalized in the past 12 months, independently of age. We observed an inverse association between the single elderly in relation to the prevalence of hypertension which may be related to the fact that these seniors are less likely to seek out a doctor or health service and therefore reported less hypertension. Being married can be a protective factor in this case.

The inverse relationship found between alcohol intake and hypertension does not agree with the data found in the literature that consumption of alcohol should be limited to two drinks per day for men and no more than one drink per day for women ${ }^{31}$. In fact, the results of the present study can be justified because it is a cross-sectional study that cannot make inferences about the time that these factors have emerged and therefore does not indicate causality.

Data from the present research revealed that only $11.1 \%$ of a total of 392 patients with hypertension participated in discussion groups for control measures of high blood pressure. The only control measure that was influenced by the elderly participation in those groups was the alimentary diet. This may explain the lack of information about the necessity of high blood pressure control and the little search for service for the same reason. When questioned about the search for control, $18.7 \%$ answered that they did not search and $11.2 \%$ only searched when they had problems.

Furthermore, to justify such behavior, $48.2 \%$ answered they did not think it was necessary. It should be highlighted that on average, those elderly with hypertension took almost 12 months to return to the doctor. This data also clarifies the absence of a difference in the use of health services between those elderly with and those without hypertension, in the search for services or some health professional between the elderly with hypertension by reported morbidity, and between elderly with and without hypertension regarding morbidity 15 days prior to the interview.

The fact that almost $50 \%$ did not seek out a health service because they considered it was not necessary reflects the absence of information about hypertension itself. The search for health services is important not only for identifying the disease, but also for the education and knowledge about how to control and avoid its evolution, thereby minimizing complications. The reported morbidity may be biased since those who seek out a doctor have a greater chance of being diagnosed.

Concerning the knowledge about measures and practices for the control of hypertension, there was no significant difference between genders. Lifestyle did not influence the knowledge about control measures of hypertension, but influenced its practice. It should be noted that smokers practice significantly less a low-salt diet and take less routine medication when compared to ex-smokers and non-smokers. Although alcohol use measured by the frequency did not show any difference when it came to controlling the disease, the CAGE test revealed that among chronic alcoholics the practice of control was lower. As regards to the influence of socioeconomic conditions on the knowledge about hypertension control, education and income were significant only for physical activity.

This result was consistent with the literature which reports that individuals with less education are more sedentary in relation to leisure activities ${ }^{32}$, are more likely to adopt unhealthy habits, present worse health indicators, and have less access to information and to health services 33 . Another study observed that the elderly with higher education levels recognized the importance and incorporated these hypertension control practices 15. The same effect of income and education upon hypertension control practices may no longer be observed in the present study.

In general, it can be concluded that the adoption of control measures for high blood pressure among the elderly is far from the ideal, which may in part be attributed to the fact that hypertension is a silent disease, and that it often does not present symptoms, if controlled with medication 34 . Thus, many individuals only treat the symptoms whenever they appear, showing the lack of understanding about the need for treatment. Another factor that should be taken into account is that because of the greater occurrence of comorbidities among the elderly, the chances of medication interaction and side effects are higher, which may lead the elderly to abandon the treatment, let alone financial issues.

A factor that influences control practice for these diseases is the bond between the patient and the health unit for follow up. Actions involving the training of health professional multipliers, screening campaigns, promoting healthy lifestyles, enrolling and follow up of people with hypertension in primary healthcare is really necessary, as are carrying out hypertension screening before the optimization of a clinical management of the disease, and the preparation of the health system to handle the demands. Screening strategies should be systematically kept by the 
government, with a guarantee of continuity and before considering an attempt of broader screening, the health system should be prepared to offer adequate treatment for new cases, and that preventive interventions are directed to individuals in greater risk 35 .

Actions to encourage practices that promote healthy habits are necessary, as are investments in adequate human resources committed to the profession and art of education; guiding and monitoring health conditions. Learning is only possible when it becomes significant and when the individual is willing to learn. Finally, it is only through knowledge that actions can be planed and social inequality barriers can be lowered.

\section{Resumen}

El objetivo de este estudio fue analizar la prevalencia de hipertensión y prácticas de control en ancianos. Un estudio transversal analizó los datos de 872 ancianos de São Paulo, Brasil, mediante una muestra por conglomerados, estratificada según la escolaridad y renta. El modelo de regresión múltiple de Poisson verificó la existencia de factores asociados a la hipertensión. La prevalencia de hipertensión referida a los ancianos fue de un 46,9\%. Las variables asociadas a la hipertensión fueron: autopercepción de salud, consumo de alcohol, sexo y hospitalización durante el último año, independientemente de la edad. Las tres medidas más adoptadas para el control de la hipertensión, aunque poco practicadas, son: tomar medicación oral de rutina, dieta sin sal, y actividad física. El estilo de vida y la condición socioeconómica no influenciaron la práctica de control, sin embargo, el conocimiento sobre la importancia de la actividad física fue mayor entre los ancianos con mayor escolaridad y renta. Se necesitan políticas de salud enfocadas a la atención primaria que incentiven cambios en el estilo de vida de los ancianos.

Hipertensión; Encuestas Epidemiológicas; Servicios de Salud; Anciano

\section{Contributors}

T. A. B. Mendes proposed the article and was responsible for the literature review, data analysis and writing up the article. M. Goldbaum provided orientation on the article proposal, data analysis and write-up. N. J. Segri assisted with the article revision, write-up and data analysis. M. B. A. Barros, C. L. G. César and L. Carandina designed the research tools, coordinated the fieldwork and contributed to the revision of the article.

\section{Acknowledgments}

We wish to thank all the elderly people that participated in this research and the support provided by the São Paulo Municipal Mayor's office and the Municipal Health Secretariat. 


\section{References}

1. World Health Organization. The World Health Report 2008: primary health care now more than ever. In: World Health Organization, editor. Advancing and sustaining universal coverage. Geneva: World Health Organization 2008. p. 23-38.

2. Caldwell JC. Population health in transition. Bull World Health Organ 2001; 79:159-60.

3. Sociedade Brasileira de Diabetes. Consenso brasileiro sobre diabetes: diagnóstico e classificação de diabetes melito e tratamento do diabetes melito tipo 2. Rio de Janeiro: Diagraphic; 2003.

4. American Heart Association. High blood pressure. (Statistical Fact Sheet 2013 Update). http:// www.heart.org/idc/groups/heart-public/@wcm/ @sop/@smd/documents/downloadable/ucm 319587.pdf (accessed on 22/May/2013)

5. Ministério da Saúde. Dia mundial do diabetes: dados estatísticos no Brasil. http://portal.saude. gov.br/portal/saude/visualizar_texto.cfm?idtxt= 29793\&janela=1 (accessed on 11/Jul/2009).

6. Sociedade Brasileira de Hipertensão. III consenso brasileiro de hipertensão arterial. São Paulo: Sociedade Brasileira de Hipertensão; 1998.

7. He J, Muntner P, Chen J, Roccella EJ, Streiffer RH, Whelton PK. Factors associated with hypertension control in the general population of the United States. Arch Intern Med 2002; 162:1051-8.

8. van Gool CH, Kempen GI, Penninx BW, Deeg DJ, van Eijk JT. Chronic disease and lifestyle transitions: results from the Longitudinal Aging Study Amsterdam. J Aging Health 2007; 19:416-38.

9. Masur J, Monteiro MG. Validation of the CAGE alcoholism screening test in a Brazilian psychiatric inpatient hospital setting. Braz J Med Biol Res 1983; 16:215-8

10. Barros AJ, Hirakata VN. Alternatives for logistic regression in cross-sectional studies: an empirical comparison of models that directly estimate the prevalence ratio. BMC Med Res Methodol 2003; 3:21.

11. Lima MG, Barros MB, César CL, Goldbaum M, Carandina L, Ciconelli RM. Impact of chronic disease on quality of life among the elderly in the state of São Paulo, Brazil; a population-based study. Rev Panam Salud Pública 2009; 25:314-21.

12. Souza JJ. Hipertensão arterial referida e uso de anti-hipertensivos em adultos na cidade de São Paulo: um estudo de base populacional [Masters Thesis]. São Paulo: Faculdade de Saúde Pública, Universidade de São Paulo; 2003.

13. National Advisory Council on Aging. Seniors in Canada 2006: report card. Ottawa: National Advisory Council on Aging; 2006.

14. Barreto SM, Passos VM, Firmo JO, Guerra HL,Vidigal PG, Lima-Costa MFF. Hypertension and clustering of cardiovascular risk factors in a community in Southeast Brazil - The Bambuí Health and Ageing Study. Arq Bras Cardiol 2001; 77:576-81.
15. Zaitune MP, Barros MB, César CL, Carandina L, Golbaum M. Hipertensão arterial em idosos: prevalência, fatores associados e práticas de controle no Município de Campinas, São Paulo, Brasil. Cad Saúde Pública 2006; 22:285-94.

16. Bassett Jr. DR, Fitzhugh EC, Crespo CJ, King GA, McLaughlin JE. Physical activity and ethnic differences in hypertension prevalence in the United States. Prev Med 2002; 34:179-86.

17. Louvison MCP, Lebrão ML, Duarte YAO, Santos JLF, Malik AM, Almeida ES. Desigualdades no uso e acesso aos serviços de saúde entre idosos do município de São Paulo. Rev Saúde Pública 2008; 42:733-40.

18. Centers for Disease Control and Prevention. Health disparities experienced by black or African Americans - United States. MMWR Morb Mortal Wkly Rep 2005; 54:1-3.

19. Travassos C, Martins M. Uma revisão sobre os conceitos de acesso e utilização de serviços de saúde. Cad Saúde Pública 2004; 20 Suppl 2:S190-8.

20. Hertz RP, Unger AN, Cornell JA, Saunders E. Racial disparities in hypertesion, prevalence, awareness and management. Arch Intern Med 2005; 165:2098-104.

21. Cacciamali MC, Hirata GI. A influência da raça e do gênero nas oportunidades de obtenção de renda - uma análise da discriminação em mercados de trabalhos distintos: Bahia e São Paulo. Estudos Econômicos 2005; 35:767-95.

22. Pascalicchio EA, Bersusa AA, Escuder MM. O cenário do acesso ao sistema de saúde da Baixada Santista dos pacientes hipertensos e ou diabéticos. In: Escuder MM, Monteiro PH, Pupo LR, organizadores. Acesso aos serviços de saúde em municípios da Baixada Santista. São Paulo: Instituto de Saúde; 2008. p. 85-96. (Temas em Saúde Coletiva, 8).

23. Noblat ACB, Lopes MB, Lopes G, Lopes AA, Salvados BA. Complicações da hipertensão arterial em homens e mulheres atendidos em um ambulatório de referência. Arq Bras Cardiol 2004; 83:308-13.

24. Barreto SM,Giatti L, Kalache A. Gender inequalities in health among older Brazilian adults. Rev Panam Salud Pública 2004; 16:110-7.

25. Travassos C, Viacava F. Acesso e uso de serviços de saúde em idosos residentes em áreas rurais, Brasil, 1998 e 2003. Cad Saúde Pública 2007; 23:2490-502.

26. Firmo JO, Lima-Costa MF, Uchôa E. Projeto Bambuí: maneiras de pensar e agir de idosos hipertensos. Cad Saúde Pública 2004; 20:1029-40.

27. Louvison MC. Desigualdades no uso e acesso aos serviços de saúde entre idosos no município de São Paulo [Masters Thesis]. São Paulo: Faculdade de Saúde Pública, Universidade de São Paulo; 2006.

28. Silva MA. Efeitos do tabagismo sobre o sistema cardiovascular, hemodinâmica e propriedades elásticas arteriais [Doctoral Dissertation]. São Paulo: Faculdade de Saúde Pública, Universidade de São Paulo; 2005. 
29. Mendes TAB, Goldbaum M, Segri N, Barros MBAB, Cesar CLG, Carandina L, et al. Diabetes mellitus: fatores associados à prevalência em idosos, medidas e práticas de controle e uso dos serviços de saúde em São Paulo, Brasil. Cad Saúde Pública 2011; 27:1233-43.

30. Francisco PMSB, Belon AP, Barros MBAB, Carandina L, Alves MCGP, Goldbaum M, et al. Diabetes auto-referido em idosos: prevalência, fatores associados e práticas de controle. Cad Saúde Pública 2010; 26:175-84.

31. Lima MG, Barros MB, Cesar CLG, Goldabum M, Carandina L, Ciconelli RM. Impact of chronic disease on quality of life among the elderly in the state of São Paulo, Brazil: a population-based study. Rev Panam Salud Pública 2009; 25:314-21.

32. Firmo JO, Uchôa E, Lima-Costa MF. Projeto Bambuí: fatores associados ao conhecimento da condição de hipertenso entre idosos. Cad Saúde Pública 2004; 20:512-21.

33. Barros MB, César CL, Carandina L, Torre GD. Desigualdades sociais na prevalência de doenças crônicas no Brasil, PNAD-2003. Ciênc Saúde Coletiva 2006; 11:911-26.
34. American Heart Association. Alcohol and blood pressure. http://www.heart.org/HEARTORG/Con ditions/HighBloodPressure/PreventionTreatmen tofHighBloodPressure/Alcohol-and-Blood-Pres sure_UCM_303244_Article.jsp (accessed on 21/ Jan/2013).

35. Zaitune MAA, Barros MB, Cesar CLG, Carandina L, Goldbaum M. Fatores associados ao sedentarismo no lazer em idosos, Campinas, São Paulo, Brasil. Cad Saúde Pública 2007; 23:1329-38.

36. Lima-Costa MF, Barreto SM, Giatti L. A situação socioeconômica afeta igualmente a saúde de idosos e adultos mais jovens no Brasil? Um estudo utilizando dados da Pesquisa Nacional por Amostra de Domicílios (PNAD 98). Ciênc Saúde Coletiva 2002; 7:813-24.

37. Sociedade Brasileira de Cardiologia. VI Diretrizes Brasileiras de Hipertensão. Arq Bras Cardiol 2010; 95(1 Suppl 1):1-51.

38. Toscano CM. As campanhas nacionais para detecção das doenças não transmissíveis: diabetes e hipertensão arterial. Ciênc Saúde Coletiva 2004; 9:885-95.

Submitted on 15/Oct/2012

Final version resubmitted on 29/Apr/2013

Approved on 08/Mai/2013 